\title{
(2) OPEN ACCESS \\ Anti-MDA5 antibody-positive dermatomyositis with rapidly progressive interstitial lung disease: report of two cases
}

\author{
Asmita A Mehta (1), ${ }^{1}$ Tisa Paul, ${ }^{1}$ Mithun $\mathrm{CB}^{2}{ }^{2}$ Nithya Haridas (ㄱ ${ }^{1}$
}

'Department of Respiratory Medicine, Amrita Institute of Medical Science, Amrita Vishwa Vidyapeetham, Kochi, Kerala, India

${ }^{2}$ Rheumatology, Amrita Institute of Medical Science, Amrita Vishwa Vidyapeetham, Kochi, Kerala, India

Correspondence to Professor Asmita A Mehta; asmitamehta@aims.amrita.edu

Accepted 31 March 2021

\section{SUMMARY}

Melanoma differentiation-associated protein 5 (MDA5) antibody-positive dermatomyositis (DM) displays unique cutaneous and pathologic features. We describe two cases of myositis-associated rapidly progressive interstitial lung disease (RP-ILD). The patients were two women from Kerala, India. Both patients had anti-MDA5 antibody-positive myositis. Both patients presented with RP-ILD without any clinical features of myositis and succumbed to their illness despite aggressive medical treatment. Anti-MDA5-antibody-positive DM is characterised by amyopathic disease with rapidly progressive and fatal ILD.

\section{BACKGROUND}

Dermatomyositis (DM) is an idiopathic autoimmune disease. It is a disease characterised by symmetric proximal muscle weakness, muscle inflammation and skin manifestations. ${ }^{1}$ Clinical features of typical cutaneous findings (eg, Gottron's papules and heliotrope rash) and proximal muscle involvement, laboratory evidence of muscle damage, pathologic correlation on biopsy and identification of myositis-specific autoantibodies can help in clinching the diagnosis. Around $50 \%-70 \%$ of the patients have myositis-specific autoantibodies while few clinically distinct phenotypes have different autoantibodies. ${ }^{23}$ This report describes two cases of DM with seropositivity to the autoantigen melanoma differentiation-associated protein 5 (MDA5). The anti-MDA5-positive DM is associated with rapidly progressive interstitial lung disease (RPILD) and high mortality.

We have described two patients who had MDA5positive DM with RP-ILD and both succumbed to their illness in spite of best possible medical care. The take home message is to highlight that anti-MDA5-positive DM is associated with rapid progression of ILD and poor outcome.

\section{CASE PRESENTATION \\ Case 1}

A 37-year-old woman presented with a history of cough, shortness of breath, myalgia and fever for 10 days. She was treated in an outside hospital for the same. In view of clinical worsening, she came to our hospital. She had a previous history of spontaneous abortion, Raynaud's phenomenon and photosensitivity.

Physical examination revealed bilateral inspiratory crackles. Arterial blood gas showed type1 respiratory failure. Chest X-ray revealed (figure 1) bilateral ground glass opacity (GGO) predominantly in lower zones. She was initiated on intravenous antibiotics and other supportives. In view of persistent hypoxemia, she was initiated on oxygen through high flow nasal cannula. Other laboratory investigations are shown in table 1 . She was found to be Anti Rho positivity (Ro 52 recombinant). As we had very high suspicion for rapidly worsening DM, myositis-specific antibody panel was sent. Sputum for acid-fast bacilli and bacterial culture were found to be negative. Serum procalcitonin was found to be $0.05 \mathrm{ng} / \mathrm{mL}$ at time of admission and $0.45 \mathrm{ng} / \mathrm{mL}$ after 5 days. After ruling out active infection, she was initiated on methylprednisolone $125 \mathrm{mg}$ intravenous two times per day in view of suspected exacerbation of mixed connective tissue disease-related ILD. Despite this, she continued to have hypoxia. On seventh day of admission, she was given first dose of cyclophosphamide ( $2 \mathrm{mg}$ / $\mathrm{kg}$ ) along with hiking up antibiotics (carbapenam). Unfortunately, her condition worsened over a period of time and required shift to intensive treatment unit (ITU) and was put on mechanical ventilation. After intubation, mini bronchoalveolar lavage (BAL) was sent for bacterial and fungal culture which was found to be sterile. Mini BAL Xpert MTB/RIF assay was negative. Blood and urine cultures were sterile. Serial chest radiographs showed worsening with increased GGOs bilaterally (figure 1, day 13). She was initiated on intravenous immunoglobulin ( $40 \mathrm{~g} /$ day) on days 12 and 13 of admission as salvage therapy. In spite of all these measures, she continued to worsen and had resistant hypoxemia. She succumbed to her illness on day 15 of admission. We received the report of myositis-specific antibody panel posthumously, which was positive for anti-MDA5 antigen (figure 2).

\section{Case 2}

A 42-year-old woman presented with reports of high-grade intermittent fever, cough with scanty expectoration and progressive shortness of breath for 1 month. Arterial blood gas (ABG) showed type 1 respiratory failure. She had history of hypothyroidism, photosensitivity and spontaneous abortion. She denied any history of recurrent oral ulcers or Raynaud's phenomenon.

Examination of respiratory system revealed bilateral late inspiratory crackles in lung bases. Chest $\mathrm{X}$-ray (figure 3) showed bilateral mid and lower zone consolidation. CT scan of the chest revealed diffuse patchy areas of GGOs along the periphery in the right upper, middle and lower lobes with bilateral dense areas of consolidation in the basal segments 


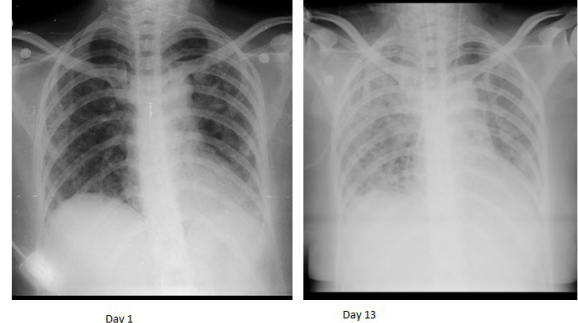

Figure 1 Showing comparison of chest radiographs (Case 1). Day 1 chest radiograh showing bilateral mid and lower zone ground glass opacities (GGO). There was obliteration of bilateral costophrenic angles. Day 13 chest radiograph showing bilateral significant increase in GGOs.

(figure 4). COVID-19 RT PCR was negative. Blood results and other investigations are shown in table 1. Atypical Pneumonia IgM IFA (IgM indirect immunoflurescent assay) was sent and was found to be negative. She was given injectable ceftriaxone and oral azithromycin along with other supportive care. She showed initial improvement with the treatment given. On the seventh day of admission, she was maintaining $96 \%$ saturation breathing $1 \mathrm{~L} / \mathrm{min}$ oxygen through nasal prongs. In view of history of photosensitivity and history of previous spontaneous abortion, connective tissue disease-associated ILD was suspected. Blood and urine culture were sterile. She developed rapid clinical and radiological worsening. On day 10 of admission, her oxygen saturation dropped to $76 \%$ and her oxygen requirement increased drastically. Procalcitonin was done to rule out worsening infection, which was found to be $0.08 \mathrm{ng} / \mathrm{dL}$. She was not fit for undergoing bronchoscopy at that point of time. The case was discussed in multidepartment meeting and she was administered methylprednisolone $1 \mathrm{~g} /$ day

\begin{tabular}{|c|c|c|}
\hline Laboratory parameter/units & Case 1 & Case 2 \\
\hline Age/gender & $37 / f e m a l e$ & 42/female \\
\hline Haemoglobin & 14.8 & 10.5 \\
\hline Total count & $7.840 \times 10^{9} / \mathrm{L}$ & $6.85 \times 10^{9} / \mathrm{L}$ \\
\hline Platelets & $25.3 \times 10^{9} / \mathrm{L}$ & $39.5 \times 10^{9} / \mathrm{L}$ \\
\hline CRP mg/L & 109 & 75 \\
\hline ESR mm/hour & 60 & 45 \\
\hline LDH U/L & Not done & 289 \\
\hline Ferritin ng/mL & 755 & 169.4 \\
\hline AST IU/L & 34.3 & 34.4 \\
\hline ALT IU/L & 25.9 & 35.1 \\
\hline Creatininie kinase U/L & 248 & 35 \\
\hline \multicolumn{3}{|l|}{ Procalcitonin (ng/mL) } \\
\hline Baseline level at admission & 0.08 & 0.06 \\
\hline On the day of worsening: & 0.45 & 0.07 \\
\hline $\mathrm{C} 3 \mathrm{mg} / \mathrm{dL}$ & 109 & 116.8 \\
\hline $\mathrm{C} 4 \mathrm{mg} / \mathrm{dL}$ & 13.6 & 26.1 \\
\hline ANA screening (IFA) & Not done & +Speckeled pattern, $2+$ \\
\hline Direct coomb's test & $1+$ & $1+$ \\
\hline Anti CCP U & 352 & Not done \\
\hline RF U & 64 & Negative \\
\hline CANCA & Not done & Negative \\
\hline PANCA & Not done & Negative \\
\hline
\end{tabular}

ALT, alanine transaminase; ANA, anti-neutrophilc antibody; C ANCA, anti neutrophil cytoplasmic antibody; AST, aspartate aminotransferase; C3, complement 3; C4, complement 4; CCP, cyclic citrullinated peptide; CRP, c reactive protein; ESR, erythrocyte sedimentation rate; $\mathrm{Hb}$, haemoglobin; $\mathrm{LDH}$, lactate dehydrogenase; RF, Rheumatoid factor.; for 3 days from 11th to 13th day of hospitalisation as suggested by rheumatologist. However, her respiratory status continued to worsen and she required mechanical ventilation. After intubation, mini BAL was sent for bacterial, fungal and mycobacterium tuberculosis (MTB) cultures that were found to be negative. Repeat blood culture at that time also came sterile. In view of rapid worsening of oxygenation status, possibility of rapidly progressive DM was considered and myositis-specific antibody panel was sent. She was administered rituximab $500 \mathrm{mg} /$ day for 1 day on the 14th day of hospitalisation in concurrence of advice of rheumatologist. But unfortunately, she continued to deteriorate. She succumbed on the 23rd day of hospitalisation. She was also found to be anti-MDA5 antibody-positive (figure 2) posthumously.

\section{DISCUSSION}

We have presented two cases of RP-ILD. Both of them had anti-MDA5 antibodies. The MDA5 protein is part of innate immune response. ${ }^{3-6}$ It elicits the production of type I immunity with release of interferon and tumour necrosis factor alpha, resulting in a cytokine storm. ${ }^{7}$ This may contribute to the pathogenesis of RP-ILD with anti-MDA5 antibody-positive DM; however, the precise pathogenesis behind RP-ILD remains unknown. ${ }^{8}$

Patients with anti-MDA5 antibody-associated DM (AMA-DM) do not have characteristic muscle weakness or elevated muscle enzymes as observed in usual DM. Serum levels for MDA5 antibodies correlate with severity of lung disease and are predictors of poor outcome. ${ }^{6-10}$ Previous reports have shown that the progressive lung disease is characterised by poor response to immunosuppressive therapy. ${ }^{7-10}$ Both of the discussed women had RP-ILD leading to hypoxic respiratory failure and they succumbed to their illness very fast. They did not respond to best possible management including rituximab or immunoglobulin.

AMA-DM-associated RP-ILD represents a unique diagnostic challenge. Clinical presentation of such patient is very similar to those with hypoxemic respiratory failure due to acute respiratory distress syndrome (ARDS). The main differential diagnosis includes atypical pneumonia, exacerbation of ILD and pneumocystis jiroveci pneumonia. ${ }^{11} \mathrm{~A}$ key distinguishing feature is the absence of clinical insult prior to the onset of ARDS. The variable presence (or complete lack) of muscle weakness or myalgia makes it difficult to recognise that the pulmonary disease is secondary to underlying myositis. ${ }^{111}$

High-resolution CT (HRCT) in such patients shows diffuse alveolar damage characterised by scattered or diffuse areas of groundglass attenuation. HRCT in RP-ILD can also show features of organising pneumonia, peribronchovascular and peripheral areas of patchy airspace consolidation and ground-glass opacities, septal thickening or traction bronchiectasis. As per American thoracic Society guidelines, myositis-related diseases should be suspected in CT patterns of concurrent non-specific interstitial pneumonia accompanied by organising pneumonia. In minority of patients of AMA-DM-related ILD, usual interstitial pneumonia pattern has been spotted. Presence of spontaneous pneumomediastinum in setting of acute hypoxemc respiratory failure should raise the suspicion of myositis-related RP-ILD. ${ }^{1}$

Lian X et al, ${ }^{11}$ have suggested 'The FLAIR Model' for mortality risk prediction in amyopathic DM associated with ILD. In their study, Lian X et al found that RPILD, HRCT imaging score, anti-MDA5 antibody, ferritin and LDH levels were associated with poor outcome in patients with AMA-DM. If a patient has positive MDA5 antibody, higher ferritin and LDH levels, even without notable respiratory manifestation, he/she is classified as mediumrisk group and has $20 \%$ risk of death. In our series, the first patient 


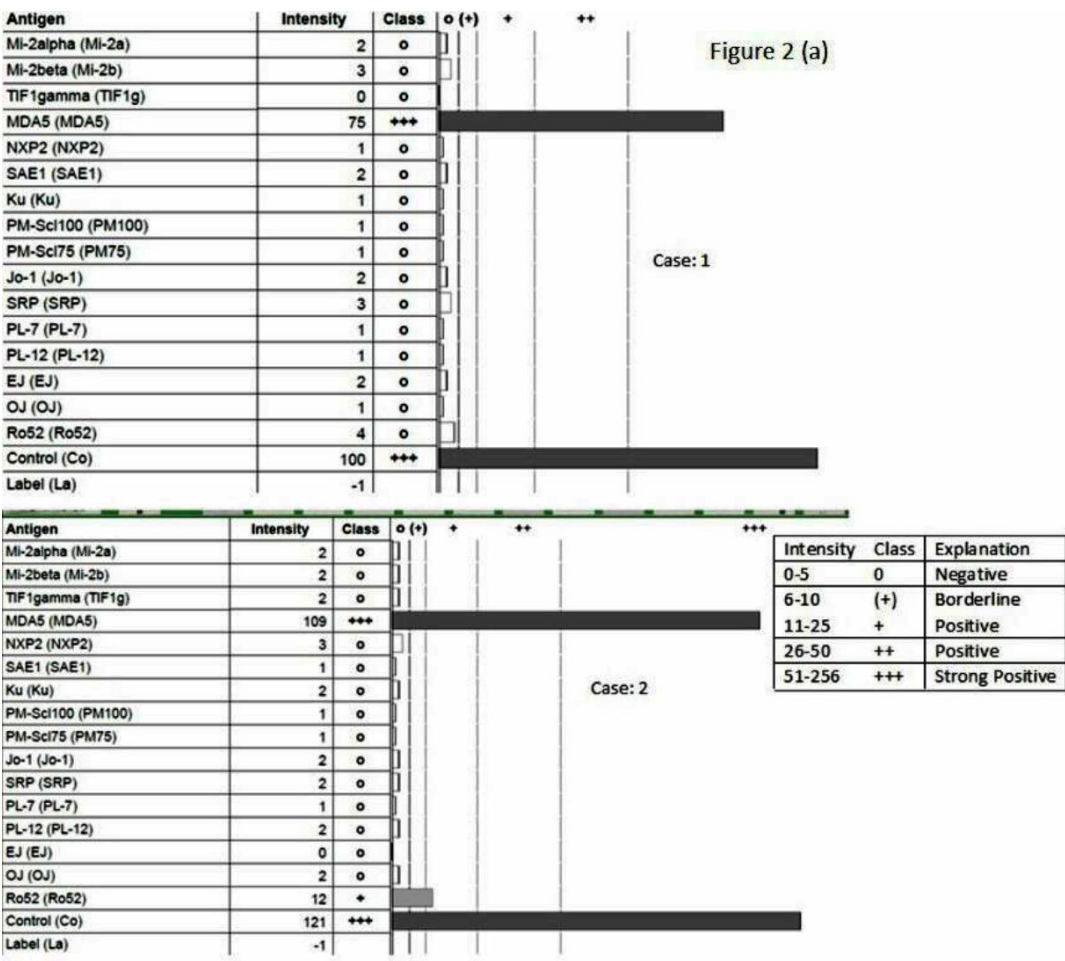

Myositis specific antibodies and their target antigen

Figure 2(b)

\begin{tabular}{|c|c|}
\hline Antigen & Targeted against \\
\hline $\begin{array}{l}\text { Mi-2 alpha (Mi2a) } \\
\text { Mi-2 beta (Mi 2b) }\end{array}$ & $\begin{array}{l}\text { Mi-2 antigen is a component of the } \\
\text { nuclesomeremodeling-deacetylase (NuRD) complex } \\
\text { involved in transcription regulation }\end{array}$ \\
\hline TIF 1 gamma (TIF g) & Transcription intermediary factor $1 Y$ (TIF1Y) \\
\hline MDA 5 & Melanoma Differentiation Asso ciated gene 5 \\
\hline NXP 2 & Nuclear Matrix Protein \\
\hline SAE 1 & Small Ubiquitin like modifier 1 activating enzyme \\
\hline Ku & $\begin{array}{l}\text { Ku is a protein heterodimer comprised of } 70 \text { and } 80 \text { Ra } \\
\text { subunits and is known for its central role in binding to } \\
\text { DNA and the double-strand break DNA repair pathway }\end{array}$ \\
\hline PM Scl 100 & Antibodies initially detected in Polymyositis and \\
\hline PM Scl 75 & $\begin{array}{l}\text { Scleroderma patients. } \\
\text { Antibodies against the } 75 \text { - and } 100-\mathrm{kDa} \mathrm{PM} / \mathrm{Scl} \text { proteins }\end{array}$ \\
\hline $\begin{array}{l}\text { Jo-1 } \\
\text { SRP }\end{array}$ & $\begin{array}{l}\text { Histidyl tRNA Synthatase } \\
\text { Signal Recognition Particle }\end{array}$ \\
\hline PL-7 & Threonyl tRNA synthetase \\
\hline $\begin{array}{l}\text { PL- } 12 \\
\text { EJ }\end{array}$ & $\begin{array}{l}\text { Alanyl tRNA synthetase } \\
\text { Glycyl tRNA synthetase }\end{array}$ \\
\hline OJ & Isoleucyl tRNA synthetase \\
\hline Ro 52 & $\begin{array}{l}\text { Anti-Sjögren's-syndrome-related antigen A } \\
\text { autoantibodies ( SSA antibody) } \\
\text { Anti Ro antibody ( Name Ro adopted from the name of } \\
\text { the first patient it was identified) } \\
\text { The Anti-SSA/Ro autoantibody targets Ro proteins, } \\
\text { namely Ro52 and Ro60. Ro52 and Ro60 were originally } \\
\text { thought to be one protein, however current findings } \\
\text { show that they are two functionally distinct proteins } \\
\text { encoded by genes on separate chromosomes }\end{array}$ \\
\hline
\end{tabular}

Figure 2 (A) Myositis panel antibody report of both cases. (B) Myositis specific antibodies and their target antigens.

had serum ferritin of $755 \mathrm{ng} / \mathrm{mL}$ while the second had $169 \mathrm{ng} / \mathrm{mL}$. The FLAIR risk score model could help physicians measure the severity of disease and predict the outcome in AMA-DM. ${ }^{11}$

It has been found that acute disease progression in anti MDA-5 RP ILD may occur within 1 year from the onset of ILD. After 1 year, survival rates are stabilised. The cause of death in most of such patients was ILD and/or its complications like secondary infection, pneumomediastinum and respiratory failure. ${ }^{1}$

DM treatment is based on the long-term administration of high doses of glucocorticoids. Immune-modulating agents (cyclophosphamide or azathioprine or mycophenolate mofetil (MMF)) are considered second-line treatment. Intravenous immunoglobulin and immunomodulators like cyclosporine A (CyA), Tacrolimus (Tac), are also recommended as add on therapy. It is advisable to treat the patients who have fulminant disease with an aggressive approach. It includes regimen of at least three agents consisting of high-dose corticosteroid, antimetabolite (MMF or azathioprine) and a third add on agent (either Tac or rituximab) for quick and potent induction of remission. ${ }^{61213}$ However, in our series, in spite

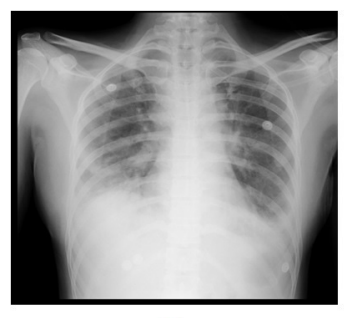

Day 1

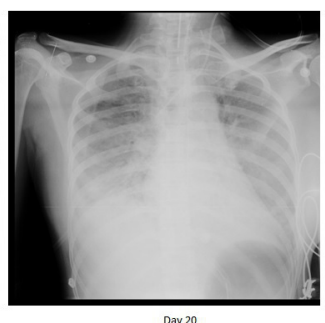

Figure 3 Showing comparison of chest radiographs (case 2). Day 1: chest radiograph showing bilateral alveolar shadows mainly in mid and lower zones (left>>right). Day 13: significant increase in alveolar infiltrates and appearance of new GGOs in both lung fields (right>>left). GGOs, ground glass opacity of aggressive treatment, we could not save any of our anti-MDA5 antibody-positive patients.

\section{OUTCOME AND FOLLOW-UP}

The prognosis of patients with ILD with anti-MDA5 antibody is very poor, in spite of early detection and intensive care. Beneficial effects of RTX in the treatment of anti-MDA5 antibody-positive patients with DM have been reported. The outcome of the two cases in our study cannot be used to definitively characterise the efficacy of RTX as it was not administered at the start of treatment in our hospital. However, we would like to highlight that it is not always possible to get the correct diagnosis immediately. Although in both cases, it was recognised that patients had some form of immune-mediated inflammatory condition, the diagnosis of anti-MDA5-positive DM took some time. The common clinical features of both our cases and its comparison to other published cases are shown in table 2 . The described cases in table 2 also highlighted the fact that many such patients can develop rapid worsening of lung disease leading to death. ${ }^{14-19}$

Awareness of anti-MDA-5 positivity gives important information about potential prognosis in such cases. In addition to MDA-5
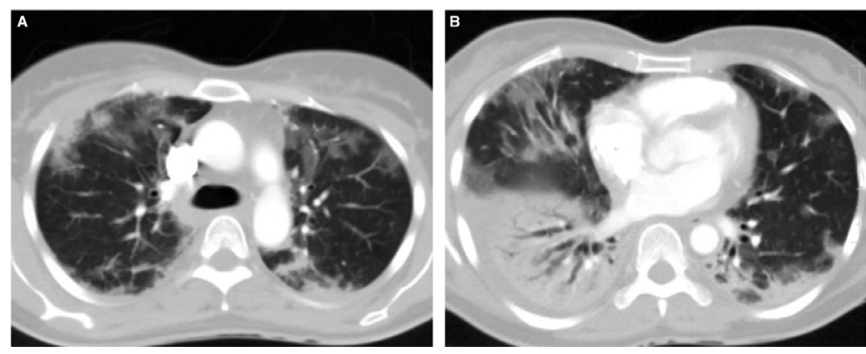

Figure 4 High resolution CT showing case 2-day 7. (A) Upper lobes showing peripheral distribution of bilateral ground glass opacity. (B) Bilateral minimal effusion, patchy distribution of ground glass opacity. 
Table 2 Clinical profile, treatment and outcome of present cases with previously published cases

\begin{tabular}{|c|c|c|c|c|c|}
\hline Ref no & Age & Sex & $\begin{array}{l}\text { Respiratory } \\
\text { symptoms }\end{array}$ & Others & Outcome \\
\hline 14 & 68 & $\mathrm{~F}$ & $\begin{array}{l}\text { Unusual } \\
\text { dyspnoea }\end{array}$ & NA & Improved \\
\hline 15 & 58 & $\mathrm{~F}$ & NA & $\begin{array}{l}\text { mPSL, PSL, } \\
\text { IVCY, IVIg,PMX }\end{array}$ & Improved \\
\hline 16 & 55 & $\mathrm{~F}$ & $\begin{array}{l}\text { Respiratory } \\
\text { failure }\end{array}$ & CPA, PE & Died \\
\hline 17 & 71 & $\mathrm{~F}$ & $\begin{array}{l}\text { Respiratory } \\
\text { failure }\end{array}$ & PSL, Tac & improved \\
\hline 18 & 71 & $\mathrm{~F}$ & $\begin{array}{l}\text { Respiratory } \\
\text { failure }\end{array}$ & $\begin{array}{l}\text { mPSL, PSL, } \\
\text { CsA, MMF, } \\
\text { Tac }\end{array}$ & Died \\
\hline 18 & 69 & $\mathrm{~F}$ & $\begin{array}{l}\text { Respiratory } \\
\text { failure }\end{array}$ & $\begin{array}{l}\text { mPSL, PSL, } \\
\text { CsA, IVCY, } \\
\text { tocilizumab, } \\
\text { CHD PSL, }\end{array}$ & Died \\
\hline 19 & 48 & M & $\begin{array}{l}\text { Respiratory } \\
\text { failure }\end{array}$ & PSL, CsA & Improved \\
\hline $\begin{array}{l}\text { Present } \\
\text { case1 }\end{array}$ & $37^{*}$ & $\mathrm{~F}$ & $\begin{array}{l}\text { Respiratory } \\
\text { failure }\end{array}$ & mPSL, RTX, IVlg & Died \\
\hline $\begin{array}{l}\text { Present } \\
\text { case2 }\end{array}$ & $42^{*}$ & $\mathrm{~F}$ & $\begin{array}{l}\text { Respiratory } \\
\text { failure }\end{array}$ & mPSL, RTX & Died \\
\hline
\end{tabular}

CHD, continuous hemodiafiltration; CPA, cyclophosphamide; CsA, Ciclosporin A; F, female; IVCY, intravenous cyclophosphamide; M, male; MMF, mycophenolate mofetil; $\mathrm{mPSL}$, methylprednisolone; NA, not available; PE, plasma exchange; PMX, polymyxin B; PSL, prednisolone; RTX, rituximab; Tac, tacrolimus.

positivity, high levels of serum ferritin, ground-glass opacities in all six lung fields and worsening of pulmonary infiltrates during treatment have been suggested as further poor prognostic factors.

Our cases can be of help to other clinicians to suspect the MDA5 DM early on. In both our cases, we found definite clinical radiological deterioration without any identifiable clinical insult. We also saw unexplained gradual worsening of dyspnoea with rapid concomitant radiological worsening. The first case in the present series prompted us to suspect the disease early in second case, but unfortunately in spite of all possible interventions, we could not save any of them.

\section{Learning points}

- Anti-melanoma differentiation-associated protein 5 antibodypositive (Anti-MDA5-Ab-positive) dermatomyositis can present with refractory or rapidly progressive interstitial lung disease as a life-threatening complication.

- Rituximab could be a useful therapy for achieving a favourable outcome.

- Some patients with anti-MDA5-positive are resistant to even intensive immunosuppressive treatments.

- Research to get early diagnosis and the establishment of other therapeutic strategies for anti-MDA5-positive patients is required.

Acknowledgements Authors would like to acknowledge contribution of $\mathrm{Dr}$ Akhilesh Kunoor Associate Professor Department of Respiratory Medicine and Dr Tajik M Shafi, Assistant Professor Department of Respiratory Medicine for their contribution to patient management.

Contributors Planning: TP, AAM. Conduct: TP, AAM, MCB, NH. Reporting: AAM. Conception and design: AAM, MCB, NH. Acquisition of data: TP. Editing and revision: $\mathrm{AAM}, \mathrm{NH}$.
Funding The authors have not declared a specific grant for this research from any funding agency in the public, commercial or not-for-profit sectors.

Competing interests None declared.

Patient consent for publication Next of kin consent obtained.

Provenance and peer review Not commissioned; externally peer reviewed.

Open access This is an open access article distributed in accordance with the Creative Commons Attribution Non Commercial (CC BY-NC 4.0) license, which permits others to distribute, remix, adapt, build upon this work non-commercially, and license their derivative works on different terms, provided the original work is properly cited and the use is non-commercial. See: http://creativecommons.org/ licenses/by-nc/4.0/.

\section{ORCID iDs}

Asmita A Mehta http://orcid.org/0000-0003-2937-0454

Nithya Haridas http://orcid.org/0000-0001-6011-5414

\section{REFERENCES}

1 Jablonski R, Bhorade S, Strek ME, et al. Recognition and management of MyositisAssociated rapidly progressive interstitial lung disease. Chest 2020;158:252-63.

2 Gerami P, Schope JM, McDonald L, et al. A systematic review of adult-onset clinically amyopathic dermatomyositis (dermatomyositis siné myositis): a missing link within the spectrum of the idiopathic inflammatory myopathies. J Am Acad Dermatol 2006;54:597-613.

3 Sato S, Hirakata M, Kuwana M, et al. Autoantibodies to a 140-kd polypeptide, CADM140 , in Japanese patients with clinically amyopathic dermatomyositis. Arthritis Rheum 2005:52:1571-6.

4 Kurita T, Yasuda S, Oba K, et al. The efficacy of tacrolimus in patients with interstitial lung diseases complicated with polymyositis or dermatomyositis. Rheumatology 2015;54:39-44.

5 Gono T, Kawaguchi Y, Satoh T, et al. Clinical manifestation and prognostic factor in anti-melanoma differentiation-associated gene 5 antibody-associated interstitial lung disease as a complication of dermatomyositis. Rheumatology 2010;49:1713-9.

6 Marie I, Dominique S, Janvresse A, et al. Rituximab therapy for refractory interstitial lung disease related to antisynthetase syndrome. Respir Med 2012;106:581-7.

7 Sem M, Molberg 0, Lund MB, et al. Rituximab treatment of the anti-synthetase syndrome: a retrospective case series. Rheumatology 2009;48:968-71.

8 Unger L, Kampf S, Lüthke K, et al. Rituximab therapy in patients with refractory dermatomyositis or polymyositis: differential effects in a real-life population. Rheumatology 2014;53:1630-8.

9 Andersson $\mathrm{H}$, Sem M, Lund MB, et al. Long-term experience with rituximab in anti-synthetase syndrome-related interstitial lung disease. Rheumatology 2015;54:1420-8.

10 Aggarwal R, Bandos A, Reed AM, et al. Predictors of clinical improvement in rituximab-treated refractory adult and juvenile dermatomyositis and adult polymyositis. Arthritis Rheumatol 2014;66:740-9.

11 Lian X, Zou J, Guo Q, et al. Mortality risk prediction in Amyopathic dermatomyositis associated with interstitial lung disease: the FLAIR model. Chest 2020;158:1535-45.

$12 \mathrm{Ge} \mathrm{Y}$, Zhou H, Shi J, et al. The efficacy of tacrolimus in patients with refractory dermatomyositis/polymyositis: a systematic review. Clin Rheumato 2015;34:2097-103.

13 Witt LJ, Demchuk C, Curran JJ, et al. Benefit of adjunctive tacrolimus in connective tissue disease-interstitial lung disease. Pulm Pharmacol Ther 2016:36:46-52.

14 Clottu A, Laffitte E, Prins C, et al. Response of mucocutaneous lesions to rituximab in a case of melanoma differentiation antigen 5-related dermatomyositis. Dermatology 2012;225:376-80.

15 Watanabe R, Ishii T, Araki K, et al. Successful multi-target therapy using corticosteroid, tacrolimus, cyclophosphamide, and rituximab for rapidly progressive interstitial lung disease in a patient with clinically amyopathic dermatomyositis. Mod Rheumatol 2016;26:465-6

16 Koichi Y, Aya Y, Megumi U, et al. A case of anti-MDA5-positive rapidly progressive interstitial lung disease in a patient with clinically amyopathic dermatomyositis ameliorated by rituximab, in addition to standard immunosuppressive treatment. Mod Rheumatol 2017:27:536-40.

17 Gono T, Sato S, Kawaguchi Y, et al. Anti-MDA5 antibody, ferritin and IL-18 are useful for the evaluation of response to treatment in interstitial lung disease with anti-MDA5 antibody-positive dermatomyositis. Rheumatology 2012;51:1563-70.

18 Tokunaga K, Hagino N. Dermatomyositis with rapidly progressive interstitial lung disease treated with rituximab: a report of 3 cases in Japan. Intern Med 2017;56:1399-403.

19 Ogawa Y, Kishida D, Shimojima Y, et al. Effective administration of rituximab in AntiMDA5 antibody-positive dermatomyositis with rapidly progressive interstitial lung disease and refractory cutaneous involvement: a case report and literature review. Case Rep Rheumatol 2017;2017:5386797 
Copyright 2021 BMJ Publishing Group. All rights reserved. For permission to reuse any of this content visit https://www.bmj.com/company/products-services/rights-and-licensing/permissions/

BMJ Case Report Fellows may re-use this article for personal use and teaching without any further permission.

Become a Fellow of BMJ Case Reports today and you can:

- Submit as many cases as you like

Enjoy fast sympathetic peer review and rapid publication of accepted articles

Access all the published articles

Re-use any of the published material for personal use and teaching without further permission

Customer Service

If you have any further queries about your subscription, please contact our customer services team on +44 (0) 2071111105 or via email at support@bmj.com.

Visit casereports.bmj.com for more articles like this and to become a Fellow 